\title{
Grazing Systems: Their Influence on Infil- tration Rates in the Rolling Plains of Texas
}

\author{
M. KARL WOOD AND WILBERT H. BLACKBURN
}

\begin{abstract}
Water infiltration rates into soils after $\mathbf{3 0} \mathrm{min}$ in shrub canopy areas and in shortgrass interspaces on the Rolling Plains were similar across grazing treatments of heavy and moderate stocking, continuous grazing; rested and grazed deferred-rotation; rested and grazed high intensity, low frequency (HILF); and two livestock exclosures which had been grazed for 20 years. The mid-grass interspace infiltration rates for the deferred-rotation treatments approached rates in the exclosures and exceeded rates in the heavily stocked, continuously grazed, and grazed HILF pastures. Infiltration rates in the HILF grazing treatments were similar to those of the heavily stocked, continuously and moderately stocked continuously grazed pastures. Infiltration rates in the rested HILF pasture were similar to those of the deferred-rotation pastures; however, the grazed HILF pasture had rates lower than the deferred-rotation pasture rates or rates of the exclosures. Aggregate stability, organic matter content, mulch, standing crop, bulk density, and ground cover significantly influenced infiltration rates.
\end{abstract}

\footnotetext{
The authors are presently assistant professor of watershed management, Department of Animal and Range Sciences and Range Improvement Task Force, New Mexico State University, Las Cruces, New Mexico 88003 and professor of watershed management, Range Science Department, Texas A\&M University, College Station, Texas 77843 .

This report is published with approval of the Director, Texas Agricultural Experiment Station as TA15674. The authors wish to acknowledge the cooperation of personnel from the Texas Experimental Ranch, Seymour.

Manuscript received December 3, 1979.
}

Water infiltration, the downward entry of water into the soil surface, is one of the most important processes of the hydrologic cycle and is of critical importance to every range manager (Johnson 1978). Infiltration rates influence soil water content, which satisfies the evapotranspiration requirements of growing plants; and water acts as a solvent for dissolved nutrients. Infiltration rates are controlled by vegetative, edaphic, climatic, and topographic influences, of which vegetation can be most easily manipulated by range managers. Kind of vegetation and amount of cover may modify soil-water relationship of a site. Grazing systems are often used to improve vegetational cover and hopefully improve infiltration rates.

Hydrologic impacts, including infiltration rates, of grazing and range improvement practices on rangeland have long been of interest to range managers and scientists. In many areas, grazing systems are partially justified by claims of improved watershed conditions. However, generalization of results from soil types and grazing conditions have caused conflicting conclusions.

Many vegetation factors, including plant and litter cover (Beutner et al. 1940, Aldon 1964, Kincaid and Williams 1966), influence infiltration rates. The amount of standing vegetation was an important influence in studies by Rauzi (1960) and McGinty et al. (1979), and infiltration rates have varied in some studies because of the vegetation type (Blackburn and Skau 1974, Smith and Leopold 1941, Box 1961, Branson et al. 1970, and Blackburn and Skau 1974). Dee et al. (1966) found infiltration rates to vary with successional stage on the same site. 
The influence of soil properties on infiltration rates has been evaluated by various researchers (Harper 1953, Gifford 1968, Branson et al. 1972, and Blackburn 1975). Differences in infiltration rates have been attributed to soil texture, structure, soil depth, bulk density, organic matter content, crusts, cracks, entrapped air, microorganisms, antecedent moisture, season of year, compaction layers, surface roughness, rock cover, and the amount of exposed bare ground.

The influence of grazing on infiltration has been studied primarily on season- or year-long pastures, and infiltration rates have been negatively correlated with stocking rates (Reed and Peterson 1961, Llacos 1962, Rauzi 1963, and Rhoades et al. 1964). Often areas which were excluded from grazing had the highest infiltration rates. Conversely, McGinty et al. (1979) found that infiltration rates under a four-pasture, three-herd deferred-rotation grazing system and a livestock exclosure were similar, and both were significantly higher than rates in a heavily stocked, continuously grazed pasture.

Objectives of this study were to determine: (1) infiltration rates into soils from a major range site under deferred-rotation; high intensity, low frequency (HILF); and continuous grazing and grazing exclusion, and (2) the impacts of grazing systems on variables which influence infiltration.

\section{Study Area}

Field research was conducted on the Texas Experimental Ranch, between Throckmorton and Seymour, Texas. The ranch is part of the Rolling Plains land resource area, which comprises approximately 6.32 million ha of rolling to rough topography in northwest Texas. Soils on the Texas Experimental Ranch are mostly clays and clay loams. Limestone parent materials are of the Admiral formation. Annual precipitation for Throckmorton County has averaged $624 \mathrm{~cm}$ over the past 40 years. The average frost-free period is 200 days. Peak periods for forage production are April, May, June, and September; however, if adequate rainfall occurs during July and August, forage production will continue at a high level throughout the summer.

Climax vegetation of the Rolling Plains included tall and midgrasses (Kothmann et al. 1970), but continuous heavy utilization by livestock and exclusion of wildfires has reduced the vegetation primarily to short and mid-grasses with varying densities of woody plants. When this study was conducted in 1977 , over $70 \%$ of the ranch's herbaceous vegetation was comprised of Texas wintergrass (Stipa leucotricha Trin. \& Rupr.), sideoats grama (Buchloe dactyloides (Nutt. Engelm.). Honey mesquite (Prosopis glandulosa Torr.) and lotebush (Ziziphus obtusifolia (T. \& G.) Gray) were the dominant woody species.

The ranch was established in 1957 for the purpose of investigating methods of improving the efficiency of cow-calf operations on native rangeland. Initially, three grazing systems were employed: (1) the two-pasture, one-herd South African switchback [2-1:3:3, 6:3, 3:6 mo] (nomenclature and notation follow Kothmann 1974); (2) a four-pasture, three-herd deferred-rotation grazing system [4-3; 12:4 mo]; and (3) a continuous grazing system with heavily stocked, moderately stocked, and lightly stocked pastures. Several pastures were designated as exclosures and have not been grazed by livestock since 1957. Comparisons of these grazing systems indicated that livestock production was greatest from the deferredrotation system (Kothmann et al. 1970).

In the fall of 1973, an eight-pasture, one-herd deferred HILF grazing system was employed [8-1; 17:119 da]. It was compared with the deferred-rotation system and the continuous system with stocking at moderate and heavy rates.

During this study stocking rates for the deferred-rotation system; HILF system; moderately stocked, continuously grazed system; and heavily stocked, continuously grazed system were $6.2,6.5$, 6.2 , and $4.6 \mathrm{ha} / \mathrm{au}$, respectively. The pasture that was evaluated in the HILF system was a lightly stocked, continuously grazed system prior to 1973
Soil series was a Leeray clay. The Leeray clay series is in the fine, montmorillonitic, thermic family of Typic Chromusterts. Leeray clay is a soil series of the clay flat range site. This series was chosen because it occurs in all the grazing treatments and accounted for $60.4 \%$ of the range site and $23.3 \%$ of the ranch's total area. The Leeray clay series and clay flat site occur extensively throughout the Rolling Plains.

The mean percentage cover of shrub canopy, midgrass, and shortgrass interspaces on the Leeray clay series of the various grazing treatments is shown in Table 1 (Wood 1979). The largest occurrence of midgrass interspace was in the exclosures followed in decreasing order by the deferred-rotation; moderately stocked, continuously grazed; HILF; and heavily stocked, continuously grazed pastures. The shortgrass interspace was found most often in the heavily stocked, continuously grazed pastures and least in the exclosures. The seral stage of the vegetation in the exclosures was high enough that shortgrass interspace was not present. The differences observed in shrub canopy between pastures of the various grazing treatments were probably the result of original brush control efficiency.

\section{Table 1. Mean percentage cover of shrub canopy area, midgrass interspace, and shortgrass interspace for various exclosures and grazing treat- ments.}

\begin{tabular}{lccc}
\hline \hline & & \multicolumn{3}{c}{$\begin{array}{c}\text { Vegetation } \\
\text { area }\end{array}$} & \\
\cline { 3 - 3 } & $\begin{array}{c}\text { Shrub } \\
\text { canopy }\end{array}$ & $\begin{array}{c}\text { Midgrass } \\
\text { interspace }\end{array}$ & $\begin{array}{c}\text { Shortgrass } \\
\text { interspace }\end{array}$ \\
\hline $\begin{array}{l}\text { Exclosure 1 } \\
\quad \text { (southern) }\end{array}$ & 16.8 & 83.2 & 1 \\
$\begin{array}{l}\text { Exclosure 2 } \\
\quad \text { (northern) }\end{array}$ & 8.4 & 91.6 & 1 \\
$\begin{array}{l}\text { Deferred-rotation } \\
\text { HILF system }\end{array}$ & 10.2 & 60.4 & 29.4 \\
$\begin{array}{l}\text { Moderately stocked, } \\
\text { continuous system }\end{array}$ & 7.6 & 48.0 & 44.4 \\
$\begin{array}{l}\text { Heavily stocked, } \\
\text { continuous system }\end{array}$ & 8.9 & 60.2 & 30.9 \\
\hline
\end{tabular}

'No shortgrass interspace was found in the exclosures.

Where the range was in good to excellent condition, shrub canopy areas occurred in a midgrass interspace matrix. Shrub canopy and patches of shortgrass interspace were located in a midgrass matrix where the range was in good to fair condition. Where the range was in fair to poor condition, shrub canopy areas and midgrass interspace patches occurred in a shortgrass matrix (Wood 1979).

\section{Methods}

\section{Infiltration}

An infiltrometer similar to the one described by Blackburn et al. (1974) was used to apply simulated rainfall to $0.5 \mathrm{~m}^{2}$ plots. Water was applied at a rate of $17.7 \mathrm{~cm} / \mathrm{hr}$ for $0.5 \mathrm{hr}$ on soil initially dry and then on the same soil 24 hours later when the soil was at or near field capacity. Only the results with the soil at field capacity are reported in this paper. The simulated rainfall rate of $17.7 \mathrm{~cm} / \mathrm{hr}$ has a natural storm return period of more than 100 years and was chosen to ensure runoff from all sites. Immediately after the first wetting, the plots were covered with a clear polyethylene plastic to reduce evaporation and maintain a uniform soil surface water content. Simulated rainfall was used for convenience, and Young and Burwell (1972) found no significant difference in runoff and erosion between simulated rainfall and natural rainfall on loamy soils in Wisconsin.

The area of accumulation of mulch and soil under woody plants was defined as the shrub canopy area, and interspace as the area between shrub canopies (Blackburn and Skau 1974). The interspaces supported midgrasses or shortgrasses. 
Infiltration is the process that divides precipitation between subsurface flow and overland flow. Infiltration rates were determined by subtracting the measured runoff from the measured precipitation at given time intervals. Runoff was collected and measured by weight at 5 -minute intervals. The weight of runoff was converted to volume $(\mathrm{cm})$ of runoff. Each plant community in each grazing treatment was randomly sampled ten times.

\section{Vegetation Cover and Standing Crop}

The percentage foliage cover of shrubs, grasses, forbs, and ground cover was determined by ocular estimate on each runoff plot from gridded sampling quadrats. Grasses, forbs, and standing dead material were harvested to a $2-\mathrm{cm}$ stubble height and mulch was collected from each plot. The material was dried at $60^{\circ} \mathrm{C}$ for 1 week and weighed.

\section{Soils}

Soil moisture by the gravimetric method (Gardner 1965) and bulk density by the core method (Black 1965) were determined for each runoff plot before each simulated rainfall application. These measurements were taken on areas adjacent to each runoff plot at depths of 0 to 3 and 5 to $8 \mathrm{~cm}$.

Soil was collected to a depth of $3 \mathrm{~cm}$ within each plot after the final simulated rainfall event. Particle size distribution of the soil was measured by the hydrometer method (Bouyoucos 1962), aggregate stability by the wet sieve method (Kemper 1965), and organic-matter content by the Walkley-Black method (Allison 1965). Microrelief within each plot was measured with a relief meter consisting of 10 pins spaced $6 \mathrm{~cm}$ apart (Kincaid and Williams 1966). A representative sample was obtained by measuring three different lines across each plot.

\section{Analysis}

Skewness and kurtosis tests were applied to each variable to determine the normality of data (Snedecor and Cochran 1971). If the data were not normally distributed, the common logarithmic transformation was applied before conducting analysis of varrance. Mean separation was accomplished with Duncan's multiple range test (Steel and Torrie 1960). Simple linear correlation and stepwise multiple regression correlation analysis determined the amount of variation in infiltration attributable to selected parameters (Table 2) (Draper and Smith 1966).

Table 2. Dependent and independent variables used in regression and correlation analysis.

\begin{tabular}{clc}
\hline \hline Number & Variable & Units \\
\hline$\hat{\mathbf{Y}}$ & Infiltration rate & $\mathrm{cm} / \mathrm{h}$ \\
$\mathrm{X} 1$ & Ground cover & $\%$ \\
$\mathrm{X} 2$ & Perennial grass cover & $\%$ \\
X3 & Total grass cover & $\%$ \\
X4 & Standing crop & $\mathrm{g} / 0.5 \mathrm{~m}^{2}$ \\
X5 & Mulch & $\mathrm{g} / 0.5 \mathrm{~m}^{2}$ \\
X6 & Bulk density, 0-3 cm depth & $\mathrm{g} / \mathrm{cm}^{3}$ \\
X7 & Organic matter content & $\%$ \\
X8 & Aggregate stability & $\%$ \\
\hline
\end{tabular}

\section{Results and Discussion}

\section{Infiltration Rates}

Across all grazing treatments, infiltration rates after 30 minutes were highest in the shrub canopy area $(15.1 \mathrm{~cm} / \mathrm{hr})$ and lowest in the shortgrass interspace $(6.0 \mathrm{~cm} / \mathrm{hr})$ with midgrass interspace being intermediate $(11.6 \mathrm{~cm} / \mathrm{hr})$ (Table 3$)$.

Infiltration rates in shrub canopy areas were similar for all grazing treatments. Highest infiltration rates occurred in exclosure 1 and lowest infiltration rates occurred in the grazed HILF treatment. The simulated rainfall application rate exceeded the infiltration rate for all treatments from 3 to $10 \mathrm{~min}$ after initial application. able 3. Infiltration rates $(\mathrm{cm} / \mathrm{hr}$ ) after $\mathbf{3 0}$ minutes for the shrub canopy zone, midgrass interspace, and shortgrass interspace for the various grazing treatments. ${ }^{1}$

\begin{tabular}{|c|c|c|c|}
\hline Grazing treatment & $\begin{array}{l}\text { Shrub } \\
\text { canopy }\end{array}$ & $\begin{array}{l}\text { Midgrass } \\
\text { interspace }\end{array}$ & $\begin{array}{l}\text { Shortgrass } \\
\text { interspace }\end{array}$ \\
\hline $\begin{array}{l}\text { Heavily stocked, } \\
\text { continuously grazed }\end{array}$ & $15.9 \mathrm{a}(\mathrm{z})$ & $8.1 \mathrm{c}(\mathrm{y})$ & 6.6 a $(y)$ \\
\hline $\begin{array}{l}\text { Moderately stocked, } \\
\text { continuously grazed }\end{array}$ & 14.7 a $(z)$ & $11.4 \mathrm{bc}(\mathrm{z})$ & 5.1 a $(y)$ \\
\hline Rested deferred-rotation & 14.9 a $(z)$ & $13.1 \mathrm{ab}(\mathrm{z})$ & $7.2 \mathrm{a}(\mathrm{y})$ \\
\hline Grazed deferred-rotation & 17.0 a $(z)$ & $13.9 \mathrm{ab}(\mathrm{y})$ & $7.9 \mathrm{a}(\mathrm{x})$ \\
\hline Rested HILF & 13.1 a $(z)$ & $9.6 \mathrm{bc}(\mathrm{yz})$ & $6.1 \mathrm{a}(\mathrm{y})$ \\
\hline Grazed HILF & $12.8 \mathrm{a}(\mathrm{z})$ & $8.2 \mathrm{c}(\mathrm{y})$ & 6.7 a $(y)$ \\
\hline Exclosure 1 & $17.2 \mathrm{a}(\mathrm{z})$ & $16.5 \mathrm{a}(\mathrm{z})$ & - \\
\hline Exclosure 2 & 15.7 a (z) & $13.9 \mathrm{ab}(\mathrm{z})$ & - \\
\hline Mean & $15.1(\mathrm{z})$ & $11.6(\mathrm{y})$ & $6.0(\mathrm{x})$ \\
\hline
\end{tabular}

'Means followed by the same letter within each column or in parentheses within each row are not significantly different at the $95 \%$ level.

In the shortgrass interspaces there were no significant differences in infiltration rates irregardless of treatment; however, the trend was for higher rates in the grazed deferred-rotation treatment and lower rates in the moderately stocked, continuously grazed treatment (Table 3). The application rate exceeded the infiltration rate shortly after initial application for all treatments (Figure 1). In the midgrass interspace the application rates exceeded the infiltration rate close to the beginning of application. Order of infiltration rates after 30 min were exclosures; deferred-rotation; moderately stocked, continuously grazed; HILF; and heavily stocked, continuously grazed.

The infiltration rates in the deferred-rotation treatment were similar to near-optimum rates of the exclosures for the midgrass interspace areas, and were higher but not significantly different

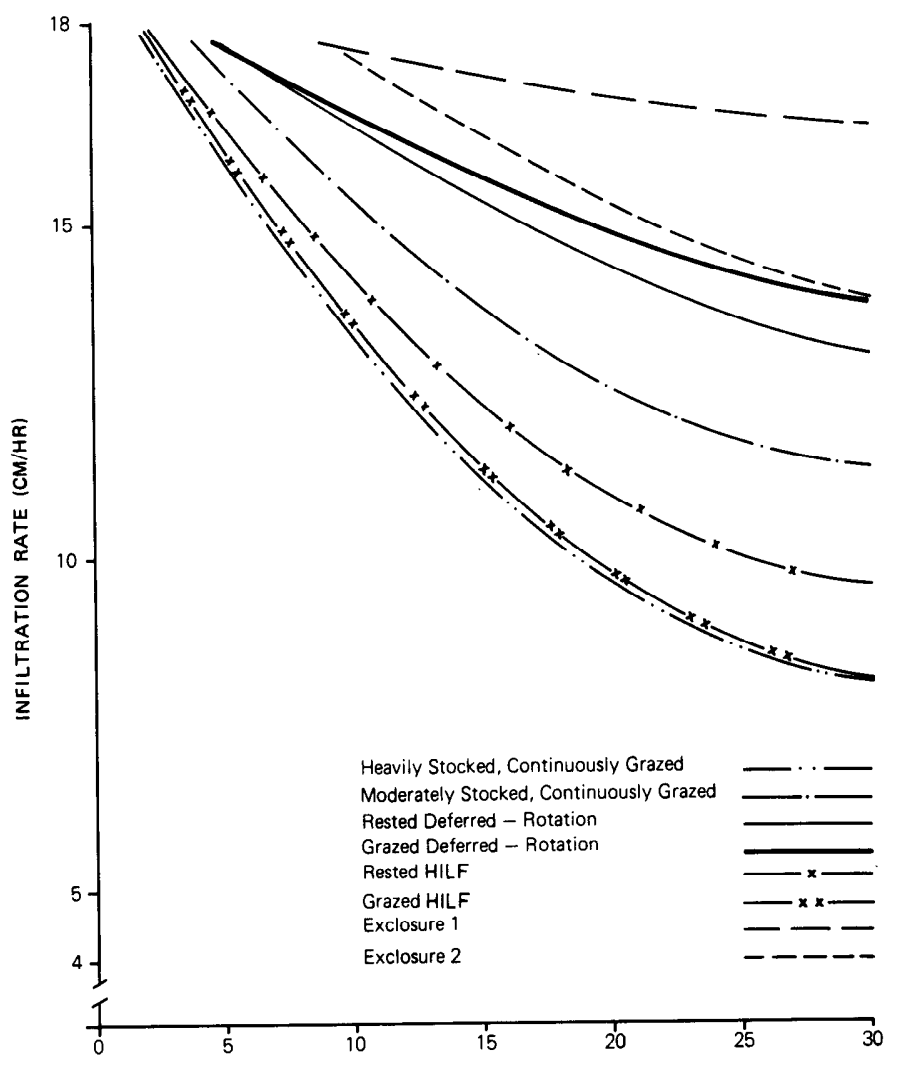

TIME (MIN)

Fig. 1. Midgrass interspace infiltration curve for the various grazing treatments. 
than the moderately stocked, continously grazed or rested HILF treatments. However, the deferred-rotation treatment rates did exceed the heavily stocked, continuously grazed, and grazed HILF treatments. The lowest infiltration rates were in the grazed HILF and heavily stocked, continuously grazed treatments, which were significantly lower than the deferred-rotation treatment and exclosures (Table 3).

Even though the infiltration rates for the shortgrass interspace areas were similar within grazing treatments, more water would infiltrate into soils of the exclosures or deferred-rotation treatments than into the soils subjected to the HILF, and heavily or moderately stocked, continously grazed treatments, because of a larger occurrence of midgrass interspace. Infiltration rates in the midgrass interspace for the heavily stocked, continuously grazed and HILF grazing treatments were similar to those of the shortgrass interspace, and were significantly lower than the shrub canopy area. Infiltration rates in the midgrass interspace for the moderately stocked, continuously grazed; rested deferredrotation; and exclosures were similar to rates of the shrub canopy area and significantly higher than the shortgrass interspace. Differences in infiltration rates in these midgrass interspace communities are important because grazing systems are applied to improve these communities over shrub canopy area and shortgrass interspace.

\section{Factors Influencing Infiltration}

The predictive equation for the dependent variables, resulting from selecting and weighing independent variables, is of the general form:

$$
\hat{Y}=a+b_{1} X_{1}+\ldots+b_{\mathrm{n}} X_{\mathrm{n}}
$$

where $\hat{Y}$ is the predicted dependent variable, $a$ is the $\mathrm{Y}$-intercept, $b$ is a regression coefficient or weighting factor, and $X$ represents the independent variables. These equations can be used to give insight into probable causative and important relationships and to predict infiltration rates on this range site under similar circumstances. The independent variables are listed in order of correlation, with the highest correlated variable being listed first. Specific infiltration ratc equations for each vegetation area and grazing treatment indicate that aggregate stability (X8) was the primary influencing factor in $86 \%$ of the equations (Table 4 ).

Aggregate stability was the most important variable in $88 \%$ of the shrub canopy areas, $100 \%$ of the midgrass interspace, and $67 \%$ of the shortgrass interspace equations. Organic matter content (X7) was most important in $9 \%$ of the equations, and mulch (X5) was the most important variable in one equation. Although organic matter content (X7) was of primary importance in only $9 \%$ of the equations, it was of secondary importance in $32 \%$ of the equations. Aggregate stability (X8) was the most important variable in all three vegetation areas and in all grazing treatments except the HILF treatment, where aggregate stability was of lesser importance. The less important role of aggregate stability (X8) in the HILF treatment was probably attributable to fewer stable aggregates, possibly owing to lower range condition and higher livestock concentrations. Variables which were not significantly correlated with infiltration rates included annual grass cover, forb cover, bulk density (5-8 cm depth), and micro-relief or roughness factor.

Coefficient of determination values $\left(R^{2}\right)$ ranged from 0.303 to 0.963 , with most of the values being between 0.6 and 0.963 . The standard errors of estimate (S.E.E.) were all less than 0.6 .

\section{Conclusions}

Infiltration rates across all treatments were significantly higher in the shrub canopy areas than in midgrass interspaces, and rates of the midgrass interspaces were significantly higher than the shortgrass interspace values. Therefore, infiltration rates can be increased by converting from shortgrass interspace to midgrass

Table 4. Infiltration rate equations for each vegetation area and grazing treatment.

\begin{tabular}{|c|c|c|c|c|}
\hline Vegetation area & Grazing treatment & Regression equations & $\begin{array}{c}\text { Coefficient of } \\
\text { determination } \\
R^{2}\end{array}$ & $\begin{array}{c}\text { Standard error } \\
\text { of estimate } \\
\text { S.E.E. }\end{array}$ \\
\hline \multirow[t]{9}{*}{ Shrub canopy } & HSCG $^{1}$ & $\hat{\mathrm{Y}}=11.463+0.137(\mathrm{X} 8)$ & 0.693 & 0.401 \\
\hline & MSCG & $\hat{\mathrm{Y}}=-0.004+0.187(\mathrm{X8})=1.647(\mathrm{X} 7)$ & 0.836 & 0.463 \\
\hline & RDR & $\hat{\mathrm{Y}}=5.290+0.176(\mathrm{X} 8)+0.011(\mathrm{X} 2)$ & 0.809 & 0.290 \\
\hline & GDR & $\hat{\mathrm{Y}}=12.783+0.033(\mathrm{X} 8)-0.039(\mathrm{X} 1)$ & & \\
\hline & & $0.590(\mathrm{X} 7)+0.0003(\mathrm{X} 5)$ & 0.910 & 0.068 \\
\hline & RHILF & $\hat{Y}=1.974+0.160(X 8)+0.808(X 7)$ & 0.837 & 0.371 \\
\hline & GHILF & $\hat{\mathrm{Y}}=7.523+0.797(\mathrm{X} 7)+0.017(\mathrm{X} 4)$ & 0.804 & 0.290 \\
\hline & E1 & $\hat{Y}=13.055+0.062(X 8)+0.0005(X 5)$ & 0.672 & 0.092 \\
\hline & E2 & $\hat{\mathrm{Y}}=8.718+0.148(\mathrm{X} 8)+0.0007(\mathrm{X} 5)$ & 0.693 & 0.412 \\
\hline Midgrass & HSCG & $\hat{\mathrm{Y}}=3.931+0.067(\mathrm{X} 8)-0.667(\mathrm{X} 1)$ & 0.747 & 0.474 \\
\hline \multirow[t]{7}{*}{ interspace } & MSCG & $\hat{\mathrm{Y}}=-10.849+0.392(\mathrm{X} 8)+1.078(\mathrm{X} 7)$ & 0.819 & 0.368 \\
\hline & RDR & $\hat{\mathrm{Y}}=-8.478+0.447(\mathrm{X} 8)+0.020(\mathrm{X} 4)-4.866(\mathrm{X} 6)$ & 0.963 & 0.268 \\
\hline & GDR & $\hat{\mathrm{Y}}=-5.447+0.294(\mathrm{X} 8)+0.021(\mathrm{X} 4)$ & 0.863 & 0.362 \\
\hline & RHILF & $\hat{\mathrm{Y}}=-3.592+0.113(\mathrm{X} 8)+0.087(\mathrm{X} 2)$ & 0.876 & 0.272 \\
\hline & GHILF & $\hat{\mathrm{Y}}=-4.527+0.212(\mathrm{X} 8)+0.895(\mathrm{X} 7)$ & 0.869 & 0.479 \\
\hline & E1 & $\hat{\mathrm{Y}}=5.984+0.123(\mathrm{X} 8)+0.765(\mathrm{X} 7)$ & 0.608 & 0.257 \\
\hline & E2 & $\hat{\mathrm{Y}}=3.815+0.149(\mathrm{X} 8)+0.056(\mathrm{X} 2)$ & 0.780 & 0.455 \\
\hline Shortgrass & HSCG & $\hat{\mathrm{Y}}=-1.186+0.068(\mathrm{X} 8)+0.068(\mathrm{X} 4)$ & 0.303 & 0.223 \\
\hline \multirow[t]{5}{*}{ interspace } & MSCG & $\hat{\mathrm{Y}}=-0.272+0.094(\mathrm{X} 8)+0.011(\mathrm{X} 8)$ & 0.674 & 0.259 \\
\hline & RDR & $\hat{\mathrm{Y}}=-12.832+0.234(\mathrm{X} 8)+1.761(\mathrm{X} 3)$ & 0.871 & 0.588 \\
\hline & GDR & $\hat{\mathrm{Y}}=-6.615=0.161(\mathrm{X} 8)+1.412(\mathrm{X} 7)$ & 0.787 & 0.316 \\
\hline & RHILF & $\hat{\mathrm{Y}}=15.289+0.845(\mathrm{X} 7)-7.115(\mathrm{X} 6)$ & 0.773 & 0.236 \\
\hline & GHILF & $\hat{\mathrm{Y}}=-6.664+0.029(\mathrm{X} 5)+0.089(\mathrm{X} 8)+0.094(\mathrm{X} 3)$ & 0.807 & 0.494 \\
\hline
\end{tabular}

${ }^{1}$ HSCG $=$ Heavily stocked, continuously grazed

MSCG $=$ Moderately stocked, continuously grazed

RDR = Rested deferred-rotation

GDR = Grazed deferred-rotation

RHILF = Rested high intensity, low frequency

GHILF $=$ Grazed high intensity, low frequency

E1 $=$ Exclosure 1

E2 $=$ Exclosure 2 
interspace or shrub canopy areas.

Infiltration rates in midgrass interspaces varied significantly among some grazing treatments. Infiltration rates in the deferredrotation treatments approached the near-optimum rates of the exclosures and exceeded those in the heavily stocked, continuously grazed treatment. Infiltration rates in the HILF treatments were similar to those of the heavily stocked, continuously grazed treatment.

The infiltration rates for the shrub canopy area or shortgrass interspaces were similar among grazing treatments. However, the pastures under deferred-rotation; moderately stocked, continuously grazed treatments, and exclosures would have higher infiltration rates because of the larger occurrence of midgrass interspace in these treatments.

Variables influencing infiltration rates include aggregate stability, organic matter content, mulch, standing crop, bulk density, initial soil moisture content ( 0 to $3 \mathrm{~cm}$ depth), ground cover, perennial grass cover, and total grass cover. The most important variable was aggregate stability followed closely by organic matter content. However, these two variables are influenced by the other independent variables.

In some ecosystems, a grazing system may not favorably influence vegetation and soils more than light or moderately stocked, continuous grazing. In ecosystems where more favorable vegetation and soil conditions are possible for implementation of a grazing system, increased infiltration can be expected. The deferred-rotation grazing system is one approach to improving infiltration rate. For the range site in this study, a deferred-rotation grazing system would be expected to result in hydrologic conditions similar to those when grazing is excluded for long periods.

\section{Literature Cited}

Aldon, E.F. 1964. Ground cover changes in relation to runoff and erosion in west-central New Mexico. U.S. Dep. Agr., Forest Serv., Rocky Mt. Forest and Range Exp. Sta. Res. Note RM-34. 4 p.

Allison, L.E. 1965. Organic carbon. In: A. Black, (ed.), Methods of soil analysis, Amer. Soc. of Agron. Series No. 9. Madison, Wis. 1572 p.

Beutner, E.L., R.R. Gaebe, and R.E. Horton. 1940. Sprinkled-plot-run off and infiltration experiments on Arizona desert soils. Amer. Geophys. Union Trans. 20:550-558.

Blake, G.F. 1965. Bulk density. In: C.A. Black (ed.), Methods of Soil Analysis, Amer. Soc. of Agron. Series No. 9. Madison, Wis. 1572 p

Blackburn, W.H. 1975. Factors influencing infiltration and sediment production of semiarid rangelands in Nevada. Water Resources Res. 11:929937.

Blackburn, W.H., and C.M. Skau. 1974. Infiltration rates and sediment production of selected plant communities in Nevada. J. Range Manage. 27:476-479.

Blackburn, W.H., R.O. Meeuwig, and C.M. Skau. 1974. A mobile infiltrometer for use on rangeland. J. Range Manage. 27:322-323.

Bouyoucos, G.J. 1962. Hydrometer method improved for making particle size analysis of soil. Agron J. 54:464-465.
Box, T.W. 1961. Relationships between plants and soils of four range plant communities in south Texas. Ecology 42:794-810.

Branson, F.A., G.F. Gifford, and J.R. Owen. 1972. Rangeland Hydrology. Soc. for Range Manage., Range Science Series No. 1. 84 p.

Branson, F.A., R.F. Miller, and I.S. McQueen. 1970. Plant communities and soil moisture relationships near Denver, Colorado. Ecology 46:311319.

Dee, R.F., T.W. Box, and E. Robertson, Jr. 1966. Influence of grass vegetation on water intake of pullman silty clay loam. J. Range Manage. 19:77-79.

Draper, N.R., and H. Smith. 1966. Applied Regression Analysis. John Wiley and Sons, Inc. New York, N.Y. 407 p.

Gardner, W.H. 1965. Water content. In: C.A. Black, (ed.), Methods of soil analysis. Amer. Soc. of Agron. Series No. 9. Madison, Wis. 1572 p.

Gifford, G.F. 1968. Rangeland and watershed management $-\mathrm{a}$ review. Univ. of Nevada Agr. Exp. Sta. Paper R-52. 50 p.

Harper, V.L. 1953. Watershed management-forest and range aspects in the United States. Unasylva 3:105-114.

Johnson, K.L. 1978. Managing livestock grazing in relation to runoff and erosion. Rangeman's Journal 5:147-149.

Kemper, W.D. 1965. Aggregate stability. In: C.A. Black, (ed.), Methods of Soil Analysis, Amer. Soc. of Agron. Series No. 9. Madison, Wis. 1572 p.

Kincaid, D.R., and G. Williams. 1966. Rainfall effects on soil surface characteristics following range improvement treatments. J. Range Manage. 19:346-351.

Kothmann, M.M. 1974. Grazing Management Terminology. J. Range Manage. 27:326-327.

Kothmann, M.M., J.W. Mathis, P.T. Marion, and W.J. Waldrip. 1970. Livestock production and economic returns from grazing treatments on the Texas Experimental Ranch. Texas Agr. Exp. Sta. B-1100. 39 p.

Llacos, L.G. 1962. Water yield as influenced by degree of grazing in the California winter grasslands. J. Range Manage. 15:34-42.

McGinty, W.A., F.E. Smeins, and L.B. Merrill. 1979. Influence of soil, vegetation and grazing management on infiltration rate and sediment production of Edwards Plateau rangeland. J. Range Manage. 32:33-37.

Rauzi, F. 1960. Plant cover increases water intake rate on rangeland soils. Crops and Soils 12:30.

Rauzi, F. 1963. Water intake and plant composition as affected by differential grazing on rangeland. J. Soil and Water Conserv. 18:114-116.

Reed, M.J., and R.A. Peterson. 1961. Vegetation, soil and cattle responses to grazing on Northern Great Plains range. U.S. Dep. Agr. Tech. Bull. 1252. $79 \mathrm{p}$.

Rhoades, E.D., F.L. Locke, H.M. Taylor, and E.H. McIllvain. 1964. Water intake on a sandy range as affected by 20 years of differential cattle stocking rates. J. Range Manage. 17:185-190.

Smith, H.L., and L.B. Leopold. 1941. Infiltration studies in the Pecos River Watershed, New Mexico and Texas. Soil Sci. 53:195-204.

Snedecor, G.W., and W.G. Cochran. 1971. Statistical Methods. Iowa State Univ. Press, Ames, Iowa. 593 p.

Steel, R.G.D., and J.H. Torrie. 1960. Principles and Procedures of Statistics. McGraw-Hill Book Co., Inc. New York, N.Y. 481 p.

Wood, M.K. 1979. The influence of grazing systems on infilt ration rate and sediment production in the Rolling Plains of Texas. Ph.D. Diss., Texas A\&M University. $117 \mathrm{p}$.

Young, R.A., and B.E. Burwell. 1972. Prediction of runoff and erosion from natural rainfall using a rainfall simulator. Soil. Sci. Amer. Proc. 36:827-380. 